\title{
KARDIOTOKSIČNOST HEMIOTERAPIJE PRVE LINIJE (GEMCITABIN/CISPLATIN I PACLITAXEL/CARBOPLATIN) KOD BOLESNIKA SA UZNAPREDOVALIM STADIJUMOM NEMIKROCELULRNOG KARCINOAM BRONHA
}

\author{
CARDIOTOXICITY OF FIRST-LINE CHEMOTHERAPY (GEMCITABIN/CISPLATIN AND \\ PACLITAXEL/CARBOPLATIN) IN PATIENTS WITH ADVANCED NON-SMALL CELL LUNG \\ CANCER
}

\section{Daliborka Bursać, Tatjana Šarčev, Aleksandar Tepavac, Bojan Zarić, Goran Stojanović}

\begin{abstract}
Sažetak: Uvod: Cilj istraživanja je bio utvrditi učestalost pojave kardiotoksičnosti kod bolesnika koji su lečeni hemioterapijom prve linije (gemcitabin/cisplatin i paclitaxel/carboplatin).

Materijal i metode: Studijom koja je bila prospektivnog karaktera obuhvaćeno 240 bolesnika sa nemikrocelularnim karcinomom bronha kliničkog stadijuma III i IV. Bolesnici su podeljeni u grupe prema vrsti hemioterapije (gemcitabin/cisplatin $i$ paclitaxel/carboplatin), kao i prema prisustvu kardiovaskularnih komorbiditeta. Pre i posle aplikacije svake serije hemioterapije je načinjen fizikalni pregled, elektrokardiogram i izmerene vrednosti NT-proBNP i troponina $T$ u serumu. Ehokardiografija je rađena pre $i$ posle hemioterapije, kao i u sklopu kontrolnih pregleda, na svaka tri meseca, ukupno godinu dana. Pojava kardiotoksičnosti je utvrđivana na osnovu prisustva kardiovaskularnih simptoma, promena u elektrokardiogramu, povišenja vrednosti NT-proBNP i troponina $T$ i sniženja istisne frakcije leve komore.

Rezultati: U sklopu studije je bilo 184 (76,7\%) muškarca. Najzastupljeniji je bio adenokarcinom, kod 120 bolesnika (50\%). Najčeśći karidovaskularni toksični efekti su bili povećanje vrednosti NT-proBNP (44.85\%), poremećaji ritma (26.18\%), venski tromboembolizam $(9.19 \%)$ i sniženje istisne frakcije leve komore (6.96\%). Kod bolesnika koji su primali hemioterapiju prve linije prema protokolu gemcitabin/cisplatin kardiotoksičnost se češće javila ukoliko su imali prethodne kardiovaskularne bolesti, ali statistička značajnost nije utvrđena. Kod bolesnika koji su primali hemioterapiju prve linije prema protokolu paclitaxel/carboplatin kardiotoksičnost se češće javila ukoliko su imali prethodne kardiovaskularne bolesti, a statistička značajnost utvrđena prilikom prvog kontrolnog pregleda kod bolesnika u III stadijumu ( $p=0.037)$.

Zaključak: Kardiotoksičnost hemioterapije se češće javlja bolesnika sa kardiovaskularnim komorbiditetima. Potrebna je bliska saradnja onkologa i kardiologa da bi se uspostavila ravnoteža između efektivnosti hemioterapije i rizika od oštećenja kardiovaskularnog sistema.
\end{abstract}

\section{Uvod}

Cilj hemioterapije je postići maksimalan efekat na tumorsko tkivo uz minimalno oštećenje zdravog tkiva, što je nekada teško postići imajuću u vidu neselektivnost citostatika. Kardiotoksičnost $u$ poslednje vreme dobija sve veći značaj, posebno zbog toga što je postignut značajan napredak kako u pogledu rane dijagnoze, tako i primene sve savremenijih lekova.

Kardiotoksičnost je prvi put uočena 1967.godine kod dece sa leukemijom koja su lečena doksorubicinom, dok veći značaj dobija od 2009.godine kada je osnovano Internacionalno udruženje za kardioonkologiju u Milanu, što predstavlja utemeljenje kardioonkologije kao nove medicinske grane.

Prema vremenu pojavljivanja mpože biti akutna (do 2 nedelje od završetka hemioterapije), subakutna (od 2 do 4 nedelje po završetku hemioterapije) i hronična ( nakon više od mesec dana po završetku aplikacije hemioterapije). Prema mehanizmu nastanka može biti tip I ili tzv antraciklinska kardiotoksičnost i tip II ili kardiotoksičnost koja se 
javlja kod primene biološke terapije (npr trastuzumab)(Tabela 1)(1,2).

\section{Tabela 1}

\begin{tabular}{|c|c|}
\hline $\begin{array}{l}\text { TIP I konvencionalna } \\
\text { hemioterapija }\end{array}$ & TIP II ciljana terapija \\
\hline Primer Doxorubicin & Primer Trastuzumab \\
\hline $\begin{array}{l}\text { Ćelijska smrt } \\
\text { Počinje pri prvoj aplikaciji }\end{array}$ & Ćelijska disfunkcija \\
\hline Patološki nalaz u bioptatu & $\begin{array}{l}\text { Bez tipičnih promena } \mathrm{u} \\
\text { bioptatu }\end{array}$ \\
\hline Zavisi od kumulativne doze & $\begin{array}{l}\mathrm{Ne} \text { zavisi od kumulativne } \\
\text { doze }\end{array}$ \\
\hline $\begin{array}{l}\text { Ireverzibilne } \\
\text { ('ćelijska smrt) }\end{array}$ & $\begin{array}{l}\text { Reverzibilne promene } \\
\text { (ćelijska disfunkcija) }\end{array}$ \\
\hline $\begin{array}{l}\text { Faktori rizika } \\
\text { Kombinovana } \\
\text { hemioterapija } \\
\text { Prethodna ili konkurentna } \\
\text { radioterapija } \\
\text { Godine starosti } \\
\text { Arterijska hipertenzija }\end{array}$ & $\begin{array}{l}\text { Faktori rizika } \\
\text { Prethodna ili konkurentna } \\
\text { antraciklinska terapija } \\
\text { Godine starosti } \\
\text { Gojaznost }\end{array}$ \\
\hline
\end{tabular}

Do sada je detaljno ispitivana $u$ područjima primene antraciklina i HER-2 antagonista, koji se najviše koriste u lečenju karcinoma dojke, ali se interes proširio na sve lekove koji se koriste $u$ lečenju malignih bolesti. Trenutno se sprovodi veliki broj istraživanja o patofiziologiji i genetskoj osnovi nastanka kardiotoksičnosti $(1,2)$.

Cilj ovod istraživanja je bio utvrditi učestalost pojave kardiotoksičnosti kod bolesnika koji su lečeni hemioterapijom prve linije (gemcitabin/cisplatin i paclitaxel/carboplatin) sa i bez prethodnih kardiovaskularnih oboljenja.

\section{Materijal i metode}

Istraživanjem koje je bilo prospektivnog karaktera i obavljeno u Institutu za plućne bolesti Vojvodine, Sremska Kamenica, Klinika za pulmološku onkologiju, Odeljenje za hemioterapiju karcinoma bronha sa Dnevnom bolnicom, u periodu od 2011. do 2013. godine obuhvaćeno je 240 bolesnika sa citološki ili patohistološki dokazanim nemikrocelularnim karcinomom bronha (NSCLC) kliničkog stadijuma III i IV, koji su bili podvrgnuti hemioterapiji prve linije prema aktuelnim protokolima.

Bolesnici su podeljeni u dve grupe, na osnovu stadijuma bolesti. U prvoj grupi su bili bolesnici $u$ III, a u drugoj grupi su bili bolesnici u IV stadijumu NSCLC. Svaka grupa je potom podeljena na na 4 podgrupe od po 30 bolesnika, zavisno od vrste hemioterapijskog protokola (gemcitabin/cisplatin ili paclitaxel/carboplatin) i prisustva kardiovaskularnih komorbiditeta

Pre i posle aplikacije svakog ciklusa hemioterapije je obavljen fizikalni pregled, načinjen elektrokardiogram i izmerene vrednosti NT-proBNP i troponina $\mathrm{T}$ u serumu. Ehokardiografija je rađena pre i posle hemioterapije, kao i u sklopu kontrolnih pregleda, na svaka tri meseca, do ukupno godinu dana. Pojava kardiološke toksičnosti je utvrđivana na osnovu prisustva kardiovaskularnih simptoma, promena u elektrokardiogramu, povišenja vrednosti NT-proBNP i troponina $T$ i sniženja istisne frakcije leve komore (Tabela 2).

Lečenje kardiotoksičnih poremećeja je sprovedeno prema preporukama Američkog udruženja za srce (American Heart AssociationAHA), Američkog koledža za kardiologiju (American College of Cardiology) i Evropskog udruženja za medikalnu onkologiju (European Society for Medical Oncology- ESMO) $(3,4)$.

Tabela 2. Protokol istraživanja

\begin{tabular}{|l|c|c|c|c|c|c|}
\hline & Uključenje & \multicolumn{1}{|c|}{$\begin{array}{c}\text { Pre } \\
\text { hemioterapije }\end{array}$} & $\begin{array}{c}\text { Posle } \\
\text { hemioterapije }\end{array}$ & $\begin{array}{c}\text { Kontrolni } \\
\text { pregled-3 mes. }\end{array}$ & $\begin{array}{c}\text { Kontrolni } \\
\text { pregled-6 mes. }\end{array}$ \\
\hline $\begin{array}{l}\text { Fizikalni } \\
\text { pregled }\end{array}$ & + & + & + & + & + \\
\hline $\begin{array}{l}\text { Kardiovaskul. } \\
\text { simptomi }\end{array}$ & + & + & + & + & + \\
\hline Ranije bolesti & + & & & & + \\
\hline Faktori rizika & + & + & + & & \\
\hline EKG & + & + & + & + \\
\hline Ehokardiografija & + & & + & + \\
\hline
\end{tabular}


NT pro-BNP

Troponin $\mathrm{T}$
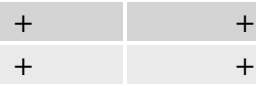

\section{Rezultati}

Od 240 ispitanika bilo je 184 (76.7\%) muškaraca i $56(23.3 \%)$ žena; odnos 3.3:1 u korist muškaraca (Tabela 3). Ustanovljena je statistički signifikantna razlika među grupama $u$ odnosu na pol $(\mathrm{p}=0.003)$, odnosno statistički značajno više muškaraca je u I-3 grupi $(93.3 \%)$, dok je statistički značajno više žena u II-4 grupi (46.7\%).

Tabela 3. Polna struktura ispitanika po grupama

\begin{tabular}{|l|c|c|c|c|c|c|}
\hline Pol & \multicolumn{2}{|c|}{ Muški } & \multicolumn{2}{c|}{ Ženski } & \multicolumn{2}{c|}{ Ukupno } \\
\hline Grupa & $\mathrm{n}$ & $\%$ & $\mathrm{n}$ & $\%$ & $\mathrm{n}$ & $\%$ \\
\hline $\mathrm{I}-1$ & 23 & 76.7 & 7 & 23.3 & 30 & 100.0 \\
\hline $\mathrm{I}-2$ & 26 & 86.7 & 4 & 13.3 & 30 & 100.0 \\
\hline $\mathrm{I}-3$ & 28 & $\mathbf{9 3 . 3}$ & 2 & 6.7 & 30 & 100.0 \\
\hline $\mathrm{I}-4$ & 25 & 83.3 & 5 & 16.7 & 30 & 100.0 \\
\hline
\end{tabular}

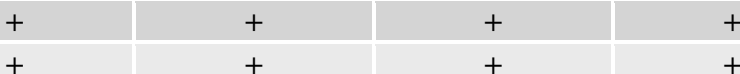

$+$

\begin{tabular}{|l|c|c|c|c|c|c|} 
III-1 & 17 & 56.7 & 13 & 43.3 & 30 & 100.0 \\
\hline II-2 & 25 & 83.3 & 5 & 16.7 & 30 & 100.0 \\
\hline II-3 & 24 & 80.0 & 6 & 20.0 & 30 & 100.0 \\
\hline II-4 & 16 & 53.3 & 14 & $\mathbf{4 6 . 7}$ & 30 & 100.0 \\
\hline Ukupno & 184 & 76.7 & 56 & 23.3 & 240 & 100.0 \\
\hline
\end{tabular}

Prosečna starost svih ispitanika je bila $63.30 \pm 8.637$ godine (opseg 34-84 godine). Najniža prosečna starost ispitanika je bila u grupi bolesnika II-1 koji su primali hemioterapiju prema protokolu gemcitabin/cisplatin u IV stadijumu NSCLC, bez

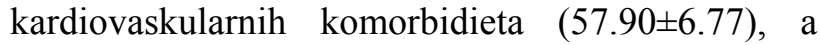
najviša u I-4 grupi, tj kod bolesnika u III stadijumu NSCLC i, koji su primali hemioterapiju prema protokolu paclitaxel/carboplatin, sa kardiovaskularnim komorbiditetima (68.37 \pm 7.57$)$, što je prikazano na Tabeli 4.

Tabela 4. Prosečna starost ispitanika po grupama

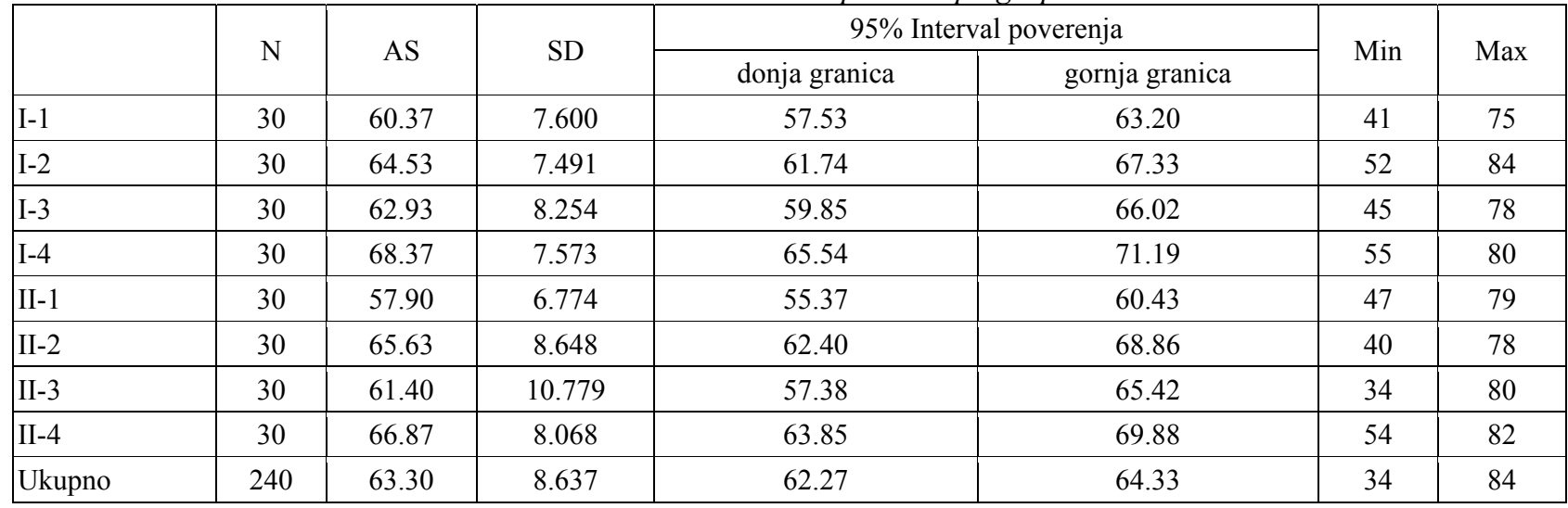

Ukoliko posmatramo distribuciju po starosnim grupama, vidimo da se najveći broj bolesnika nalazi u grupi od 60-69 godina, Grafikon 1.

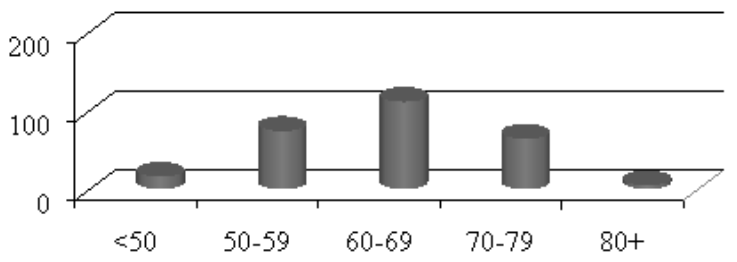

Grafikon 1. Prikaz starosnih grupa ispitanika

U odnosu na patohistološki tip karcinoma najveći broj bolesnika ima adenokarcinom (120 bolesnika ili
50\%), potom skvamozni karcinonom (108 bolesnika ili 45\%). Makrocelularni karcinom je verifikovan kod jednog bolesnika $(0.4 \%)$ i kod 11 bolesnika (4.6\%) ostale vrste karcinoma. U odnosu na vrstu karcinoma nije ustanovljena statistički signifikantna razlika po grupama Tabela $5,(\mathrm{p}=0.578)$.

Tabela 5. Patohistološki tip karcinoma po grupama

\begin{tabular}{|l|c|c|c|c|c|}
\hline \multirow{2}{*}{ GRUPA } & \multicolumn{4}{|c|}{ Patohistološki tip karcinoma } & \multirow{2}{*}{ Ukupno } \\
\cline { 2 - 5 } & Adeno & Skvamoz. & Makro & Ostali & Uky \\
\hline I-1 & $16-53.3 \%$ & $13-43.3 \%$ & $0-0.0 \%$ & $1-3.3 \%$ & $30-100.0 \%$ \\
\hline I-2 & $15-50.0 \%$ & $13-43.3 \%$ & $0-0.0 \%$ & $2-6.7 \%$ & $30-100.0 \%$ \\
\hline
\end{tabular}




\begin{tabular}{|l|c|c|c|c|c|}
\hline I-3 & $15-50.0 \%$ & $14-46.7 \%$ & $0-0.0 \%$ & $1-3.3 \%$ & $30-100.0 \%$ \\
\hline I-4 & $8-26.7 \%$ & $22-73.3 \%$ & $0-0.0 \%$ & $0-0.0 \%$ & $30-100.0 \%$ \\
\hline II-1 & $19-63.3 \%$ & $10-33.3 \%$ & $0-0.0 \%$ & $1-3.3 \%$ & $30-100.0 \%$ \\
\hline II-2 & $16-53.3 \%$ & $13-43.3 \%$ & $0-0.0 \%$ & $1-3.3 \%$ & $30-100.0 \%$ \\
\hline II-3 & $16-53.3 \%$ & $10-33.3 \%$ & $1-3.3 \%$ & $3-10.0 \%$ & $30-100.0 \%$ \\
\hline II-4 & $15-50.0 \%$ & $13-43.3 \%$ & $0-0.0 \%$ & $2-6.7 \%$ & $30-100.0 \%$ \\
\hline Ukupno & $120-50 \%$ & $108-45 \%$ & $1-0.4 \%$ & $11-4.6 \%$ & $240-100.0 \%$ \\
\hline
\end{tabular}

U odnosu na pušački status među ispitanicima je bilo $164(68.3 \%)$ pušača, $59(24.6 \%)$ bivših pušača i 17 (7.1\%) nepušača, Grafikon 2. Nije ustanovljena statistički značajna razlika među grupama u odnosu na pušački status ( $\mathrm{p}=0.145)$.

Ukoliko bolesnike podelimo na grupu sa $i$ grupu bez kardiovaskularnih komorbititeta i posmatramo pušački status ustanovljena je statistički značajna razlika među grupama u korist bolesnika koji su imali kardiovaskularne komorbiditete $(\mathrm{p}=0.010)$.

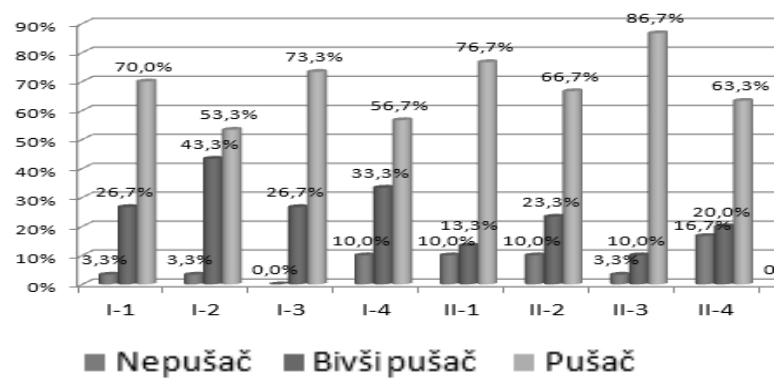

Grafikon 2. Pušački status ispitanika

Najčešći karidovaskularni toksični efekti su bili povećanje vrednosti NT-proBNP (44.85\%), poremećaji ritma (26.18\%), venski tromboembolizam $(9.19 \%)$ i sniženje istisne frakcije leve komore $(6,95 \%)$, Grafikon 3.

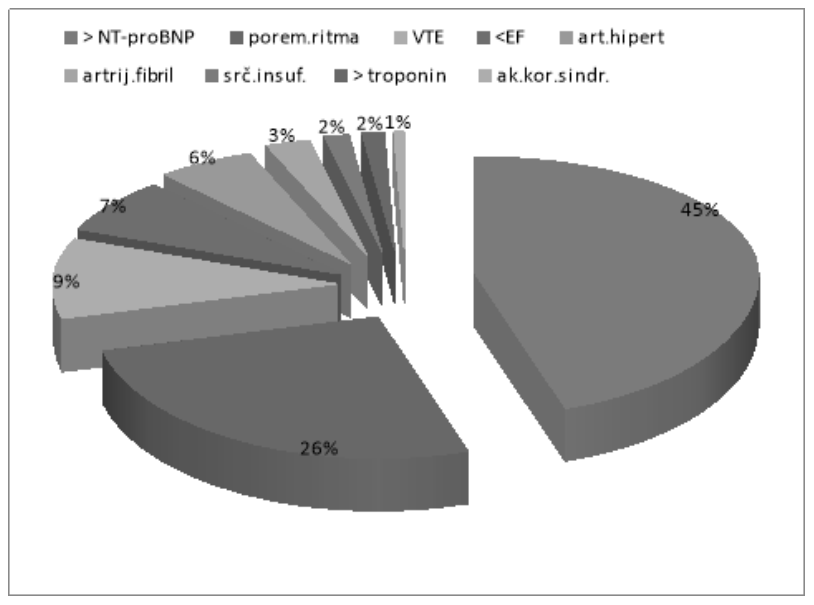

\section{Grafikon 3. Prikaz kardiotoksičnih efekata}

Posmatrali smo učestalost kardiotoksičnosti kod bolesnika u III stadijumu NSCLC koji su primali hemioterapiju prema protokolu gemcitabin/cisplatin $\mathrm{u}$ odnosu na prisustvo kardiovaskularnih komorbiditeta i ustanovili da se češće javila ukoliko su imali prethodne kardiovaskularne bolesti, ali statistička značajnost nije utvrđena (po hemioterapijskim ciklusima i kontrolnim pregledima statistička značajnost je bila $p=0.792, p=0.796, p=0.434$, $\mathrm{p}=1.000, \mathrm{p}=0.792, \mathrm{p}=0.584 \mathrm{i} \mathrm{p}=0.542$, respektivno). Kardiotoksičnost se češće javila kod bolesnika u IV stadijumu NSCLC sa kardiovaskularnim komorbiditetima koji su primali hemioterapiju prema protokolu gemcitabin/cisplatin, ali nije ustanovljena statistička značajnost (po hemioterapijskim ciklusima i kontrolnim pregledima statistička značajnost je bila $\mathrm{p}=0.313, \quad \mathrm{p}=0.222, \quad \mathrm{p}=0.371, \quad \mathrm{p}=0.347, \quad \mathrm{p}=0.278$, $\mathrm{p}=1.000 \mathrm{i} \mathrm{p}=0.718$, respektivno).

Učestalost kardiotoksičnosti kod bolesnika u III stadijumu NSCLC koji su primali hemioterapiju prema protokolu paclitaxel/carboplatin je češća ukoliko su imali prethodne kardiovaskularne bolesti, ali je statistički značajna razlika ustanovljena na prvom kontrolnom pregledu (mesec dana nakon završetka hemioterapije $\mathrm{p}=0.037$ ). Učestalost kardiotoksičnosti kod bolesnika u IV stadijumu NSCLC koji su primali hemioterapiju prema protokolu paclitaxel/carboplatin je češća kod bolesnika koji su imali prethodne kardiovaskularne bolesti, ali statistički značajna razlika nije utvrđena (statistička značajnost u toku hemioterapijskih ciklusa i kontrolnih pregleda je bila $\mathrm{p}=0.228, \mathrm{p}=0.371, \mathrm{p}=0.390, \mathrm{p}=1.000$, $\mathrm{p}=0.129, \mathrm{p}=0.488 \mathrm{i} \mathrm{p}=0.448$, respektivno).

\section{Diskusija}

Želeli smo naglasiti značaj adekvatne procene kardijalnog statusa u cilju selekcije bolesnika za aplikaciju hemioterapije, kako bi imali što bolji efekat uz što manje štetnih nuspojava.

Istraživanja o kardiotoksičnosti su se do sada uglavnom sprovodila na području primene hemioterapije karcinoma dojke, s obzirom da se lekovi kod kojih se ispoljila kardiotoksičnost (doxorubicin i trastuzumab) najviše koriste upravo u lečenju te maligne bolesti. Međutim, vremenom se interes za kardiotoksičnost proširio na sve lekove koji se koriste u medicinskoj onkologiji. U velikom registru koji 
obuhvata preko 40.000 bolesnica sa karcinomom dojke iz SEER baze podataka, je dokazano da koronarna arterijska bolest, emfizem, dijabetes, arterijska hipertenzija i periferna vaskularna bolest predstavljaju signifikantne faktore rizika za pojavu srčane insuficijencije nakon aplikacije hemioterapije (5).

Wacheters i saradnici su ispitivali pojavu kardiotoksičnosti kod bolesnika sa uznapredovalim NSCLC koji su lečeni hemioterapijom prve linije prema protokolu gemcitabin/cisplatin i epirubucin/gemcitabin. Ispitivanjem je obuhvaćeno ukupno 68 bolesnika, u III i IV stadijumu bolesti, ECOG performans statusa $0-2$, prosečne starosti 61 godinu, koji su primali navedenu terapiju. U istraživanje su uključeni bolesnici bez i bolesnici sa prethodnim kardiovaskularnim oboljenjima. Pojava kardiotoksičnosti je evaluirana merenjem ejekcione frakcije leve komore MUGA skeniranjem (radionuklidna angiografija ili multi-gated acquisition), pre kao i 12 nedelja posle hemioterapije. Kod bolesnika koji su primali hemioterapiju prema protokolu gemcitabin/cisplatin kardiotoksičnost u vidu smanjenja EF se javila kod 23\% bolesnika (kod 7\% bolesnika smanjenje EF je bilo veće od $20 \%$ od bazičnih vrednosti). U grupi bolesnika koji su primali hemioterapiju prema protokolu gemcitabin/epirubicin kardiotoksičnost se javila kod 55\% bolesnika (kod $13 \%$ bolesnika smanjenje EF je bilo veće od $20 \%$ u odnosu na bazične vrednosti). Do većeg smanjenja vrednosti ejekcione frakcije je došlo kod bolesnika koji su imali prethodna kardiovaskularna oboljenja, kao što je infarkt miokarda, aortna stenoza ili mitralna regurgitacija, ali bez statističke značajnosti, $\mathrm{p}=0.265 \mathrm{U}$ jednom od zaključaka ove studije autori su naglasili da gemcitabin u sklopu polihemioterapijskih protokola može dovesti do subkliničkih oštećenja srca (6). S obzirom na širu definiciju kardiotoksičnosti koju smo mi primenili u našem istraživanju, pridržavajući se preporuka Nacionalnog instituta za karcinom-National Cancer Institute, mi smo dobili širi spektar kardiotoksičnih pojava,a smanjenje ejekcione frakcije se javilo kod ukupno $6.95 \%$ bolesnika.

Hardy i saradnici su 2010. godine objavili rezultate velikog istraživanja koje je obuhvatilo preko 34.000 bolesnika sa NSCLC stadijuma I-IV koji u vreme postavljanja dijagnoze maligne bolesti nisu imali prethodne kardiovaskularne bolesti. Bolesnici su bili podeljeni u tri grupe; bolesnike koji su dobijali samo hemioterapiju, bolesnike koji su dobijali samo radioterapiju i bolesnike koji su lečeni hemioradioterapijom. Nama je posebno interesantna grupa bolesnika $(9.4 \%)$ koja je primala samo hemioterapiju, s obzirom da su bolesnici praćeni u toku 12 meseci, što je bio dizajn i našeg ispitivanja. $U$ toku tih 12 meseci bolesnici nisu dobijali nikakav drugi vid terapije, što je omogućilo adekvatno praćenje poremećaja kardiovaskularnog aparata. Ishemijska bolesti srca i srčana insuficijencija su bili najčešći kardiovaskularni poremećaji koji su se javili u grupi bolesnika koji su primali hemioterapiju (7). U svom radu Rowinski i saradnici naglašavaju da u toku aplikacije paclitaxela, bez obzira da li se radi o monoteraopiji ili polihemioterapiji, može doći do različitih reakcija u vidu bradiaritmija, tahiaritmija, AV blokova i ishemijskih pojava (8). Prema izveštaju Agencije za hranu i lekove (FDA-Food and Drug Administration) iz maja 2014.godine od 21.486 bolesnika koji su imali nuspojave prilikom primene paclitaxela 26 bolesnika $(0.12 \%)$ je imalo kardiotoksičnost. Taj broj predstavlja $0.55 \%$ od svih bolesnika koji su imali kardiotoksičnost uopšte (9).

\section{Zaključak}

Prema rezultatima našeg istraživanja kardiotoksičnost hemioterapije se češće javlja kod bolesnika koji imaju kardiovaskularne komorbiditete. Uspostavljanje ravnoteže između efektivnosti hemioterapije i rizika od oštećenja kardiovaskularnog sistema zahteva blisku saradnju onkologa i kardiologa, sa ciljem kreiranja individualne terapije za svakog bolesnika.

\section{Literatura}

1. Sheppard RJ, Berger, J and Sebag IA, Cardiotoxicity of Cance Terapeutics: Current Issues in Screening, Prevention and TherapyCardiotoxicity of Cancer Therapeutics, Front Pharmacol 2013;4:19.

2. Albini A, Pennesi G, Donatelli F, Cammarota R, De Flora S, and Noonan DG. Cardiotoxicity of Anticancer Drugs: The Need for Cardio-Oncology and CardioOncological Prevention, J Natl Cancer Inst 2010;102(1):14-25.

3. AHA The American Heart Association, Available at: http://www.heart.org/HEARTORG/ (updates 2011, Date last accessed 01.maj,2014)

4. Curigliano G, Cardinal D, Suter T, Plataniotis G, de AzambujaE , Sandri M. T at al, Cardiovascular toxicity induced by chemotherapy, targeted agents and 
radiotherapy: ESMO Clinical Practice Guidelines, Ann Oncol 2012;23(7):155-66.

5. Pinder, M. C., Duan, Z., Goodwin, J. S., Hortobagyi, G. N., and Giordano, S. H. Congestive heart failure in older women treated with adjuvant anthracycline chemotherapy for breast cancer. J Clin Oncol 2007; 25:3808-15.

6. Wachters FM et al. Cardiotoxicity in Advanced Nonsmall Cell Lung Cancer Patients Treated with Platinum and Non-platinum Based Combinations as First-line Treatment. Anticancr Research 2004;24:2079-84.
7. Hardy D. et al. Cardiac toxicity in association with chemotherapy and radiation therapy in a large cohort of older patients with non-small-cell lung cancer Ann Oncol 2010 first published online March 8, 2010 doi:10.1093/annonc/mdq042

8. Rowinsky EK, McGuire WP, Guarnieri T, Fisherman JS, Christian MC, Donehower RC. Cardiac disturbances during the administration of taxol J Clin Oncol 1991;9:1704-12.

9. eHealthMe FDA and Social Media, Personalized Available from: http://www.ehealthme.com/. Date last accessed 20 oct.2014)

Introduction: The aim of this study was to establish the frequency of cardiotoxicity in the patients treated with the first-line chemotherapy (gemcitabine/cisplatin and paclitaxel/carboplatin).

Patients and Methods: This prospective study included 240 patients with cytologically or histopathologically confirmed NSCLC at the clinical stages III and IV. Patients are divided into subgroups according to the type of chemotherapy (gemcitabine/cisplatin and paclitaxel/carboplatin) and the presence of cardiovascular co-morbidities. Physical examination, electrocardiogram and NTproBNP and troponin $T$ levels were performed before and after the application of each cycle of chemotherapy. Echocardiography was performed before and after chemotherapy, as well as in the follow-up examinations every three months, a total of one year. Cardiac toxicity was determined based on the presence of cardiovascular symptoms, changes in the electrocardiogram, elevated levels of NTproBNP and troponin $T$ and a decrease in left ventricular ejection fraction.

Results: In the study group 184 patients (76.7\%) were male. The most frequent was adenocarcinoma, in 120 patients (50\%). Most common cardiovascular toxic effects were increase in the level of NTproBNP (44.85\%), cardiac arrhythmias (26.18\%), venous thromboembolism (19.9\%) and decreased left ventricular ejection fraction (6.96\%). Patients treated with the first-line chemotherapy gemcitabine/cisplatin developed cardiotoxicity more frequently if they had a former history of cardiovascular diseases, but without statistical significance. Patients treated with the first-line chemotherapy paclitaxel/carboplatin developed cardiotoxicity more frequently if they had a former history of cardiovascular diseases, and the statistical significance was registered at the first follow-up examination in stage III NSCLC patients ( $p=0.037)$.

Conclusion: Chemotherapy induced cardiotoxocity frequently occurs in patients with cardiovascular co-morbidities. Balance between the effectiveness of chemotherapy and the risk of cardiotoxicity requires close cooperation oncologists and cardiologists.

Daliborka Bursać

Institut za plućne bolesti Vojvodine,

Klinika za pulmološku onkologiju,

Sremska Kamenica

e-mail:dadabursac@gmail.com 